\title{
KELAYAKAN USAHATANI CABAI MERAH \\ DENGAN SISTEM \\ PANEN HIJAU DAN SISTEM PANEN MERAH \\ (Kasus Pada Petani Cabai di Kecamatan Sariwangi Kabupaten Tasikmalaya)
}

\author{
Oleh : \\ DEDI DJULIANSAH \\ DOSEN PRODI AGRIBISNIS FAKULTAS PERTANIAN \\ UNIVERSITAS SILIWANGI \\ e-mail : dedidjuliansah@ rocketmail.com
}

\begin{abstract}
Abstrak
Penelitian ini bertujuan untuk mengetahui tingkat kelayakan usahatani cabai dilihat dari system panen yang dilakukan petani yaitu sistem panen merah dan yang melakukan sistem panen hijau di Kecamatan Sariwangi Kabupaten Tasikmalaya.

Metode yang digunakan dalam Penelitian ini adalah metode survey, adapun data yang digunakan terdiri dari data primer dan sekunder. Penentuan petani sampel memakai metode sampel acak proporsional (proporsional random sampling), jumlah responden yang diambil sebanyak 36 petani, terdiri dari petani cabai yang melakukan panen merah sebanyak 9 orang dan petani cabai yang melakukan panen sistem hijau sebanyak 27 orang.

Hasil penelitian menunjukkan bahwa usahatani cabai dengan sistem panen merah lebih besar baik dilihat dari segi biaya yang dikeluarkan maupun dari penerimaan dan pendapatan yang diperoleh serta nilai R-C yang dihasilkan.
\end{abstract}

Kata Kunci : Cabai, Sistem Panen Hijau, Sistem Panen Merah

\section{PENDAHULUAN}

Pembangunan pertanian yang mencakup tanaman pangan, perikanan, peternakan, Serta perkebunan dan kehutanan harus diarahkan pada perkembangan yang lebih maju, efisien, dan tangguh. Khususnya dalam pembangunan subsektor tanaman Hortikultura harus diarahkan untuk meningkatkan kualitas produk sehingga pada akhirnya hassil produk tersebut selain untuk memenuji permintaan dalam juga agar dapat bersaing di pasaran dunia.

Tingginya penggunaan sarana produksi pada usahatani cabai pada akhirnya akan membawa konsekwensi pada pendapatan yang akan diperoleh oleh petani dan pada akhirnya akan berpengaruh terhadap kesejahteraan petani dan keluarganya.

Wilayah Kecamatan Sariwangi merupakan wilayah nomor dua terluas penanaman cabai di Kabupaten Tasikmalaya pada tahun 2006, selain itu wilayah tersebut menunjukkan perkembangan penanaman cabai yang terus bertambah. Namun dari luas panen 102 hektar, yang dilakukan panen merah sekitar 35 persen (35,7 hektar) sedangkan yang dipanen hijau lebih banyak yaitu sekitar 65 persen (66,3 hektar).

Harga cabai sangat berfluktuatif sekali tergantung musim dan permintaan pasar, disamping itu terdapat perbedaan harga yang signifikan antara cabai dipanen hijau dan harga cabai dipanen merah. Harga cabai dipanen merah biasanya lebih mahal dibanding dengan harga cabai hijau, selain itu ketahanan cabai merah lebih baik daripada cabai hijau. Namun untuk melakukan pemanenan cabai merah memerlukan biaya tambahan dan resiko adanya serangan hama atau penyakit.

Upaya yang dilakukan Pemerintah dalam rangka meningkatkan kualitas cabai (panen Merah) adalah dengan memberikan bantuan dana kepada petani yang ditujukan untuk membantu petani agar mau memanen cabainya setelah cabai tersebut merah, tetapi pada kenyataannya walaupun bantuan dana tersebut telah digulirkan namun masih banyak petani yang tetap melakukan pemanenan pada saat buah cabai dalam keadaan masih hijau. 


\section{A MIMBAR AgRIBISNIS

Berdasarkan hal tersebut di atas maka perlu dikaji sampai seberapa jauh keuntungan yang diperoleh petani cabai dengan cara pemanenan hijau dan cara pemanenan merah.

Berdasarkan uraian pada latar belakang, dapat diidentifikasikan masalahnya adalah sampai seberapa besar kelayakan usaha yang diperoleh petani cabai dengan sistem panen hijau dan sistem panen merah dilihat dari aspek biaya dan pendapatan.

Penelitian ini bertujuan untuk mengetahui kelayakan usaha petani cabai yang melaksanakan pemanenan dengan sistem hijau dan sistem merah

Hasil penelitian ini diharapkan berguna untuk:

1. Tambahan informasi untuk penelitian lebih lanjut

2. Pemerintah, sebagai masukkan dalam menentukan kebijakkan pembangunan sub-sektor Hortikultura.

3. Petani, memberikan gambaran usahatani yang sedang dilaksanakannya

Biaya pemeliharaan pada budidaya cabai sistem panen merah lebih besar daripada cabai sistem hijau. Oleh karena itu walaupun usahatani cabai merah memerlukan biaya yang lebih besar daripada cabai hijau, namun akan mempengaruhi laba dari usahatani tersebut. Hal ini sejalan dengan pendapat Soeharjo (1980), bahwa tiap kegiatan dibidang produksi, tataniaga, dan pembangunan sektor pertanian, pada akhirnya akan dinilai dari biaya yang dikeluarkan, dan hasil yang diterima, selisih keduanya disebut pendapatan kegiatan usaha.

Mubyarto (1982), mengemukakan bahwa pendapatan petani produsen diperhitungkan dengan jalan mengurangi penerimaan dengan biaya produksi yang telah diperhitungkan dengan bunga modal. Hal ini sejalan dengan pendapat Adiwilaga (1982) yang mengemukakan bahwa pada kegiatan usahatani, pendapatan diketahui dengan cara mengurangi nilai hasil produksi dengan seluruh biaya yang dikeluarkan selama satu musim tanam. Sedangkan Soekartawi (1985), mengemukakan bahwa penerimaan adalah nilai hasil produksi yang diperoleh dari suatu kegiatan dalam waktu tertentu.
Tingkat keuntungan dan efisiensi penggunaan biaya usahatani dapat dijadikan parameter baik tidaknya suatu usahatani, yakni semakin tinggi keuntungan yang diperoleh dari suatu kegiatan usahatani, maka semakin baik kegiatan usahatani, demikian pula semakin efisien suatu usahatani, maka semakin baik pula suatu kegiatan usahatani (Mubyarto, 1982).

\section{METODELOGI PENELITIAN Metode penelitian}

Metode penelitian yang digunakan dalam penelitian ini adalah metode survai. Dalam metode ini tidak semua populasi diwawancarai, tetapi responden yang menjadi sampel saja, sebagaimana yang dikemukakan oleh Nazir (1998) yang menyatakan bahwa metode survai adalah penelitian yang diadakan untuk memperoleh fakta-fakta dari gejala-gejala yang ada dan mencari keterangan-keterangan secara faktual, baik tentang institusi sosial, ekonomi, politik dari suatu kelompok, maupun suatu daerah.

\section{Teknik Pengumpulan Data}

Data yang dikumpulkan dalam penelitian ini yaitu berupa data primer dan data sekunder. Data primer diperoleh dengan cara wawancara langsung kepada responden dengan menggunakan daftar pertanyaan (kuesioner) yang terstruktur. Sedangkan data sekunder diperoleh dari Dinas dan Instansi terkait serta dari literatur-literatur yang ada hubungannya dengan penelitian ini.

\section{Teknik Penarikan Sampel}

Terpilihnya Kecamatan Sariwangi sebagai sampel yaitu secara disengaja (purposif) dengan pertimbangan karena disamping lahan pertanaman cabai kedua terluas di Kabupaten Tasikmalaya, juga kelompoktaninya telah mendapat dana Bantuan Permodalan Langsung Masyarakat (BPLM) untuk komoditas hortikultur (cabai merah) tahun 2005.

Teknik penarikan sampel yang digunakan adalah sampling klaster, dalam sampling ini, populasi dibagi-bagi menjadi beberapa kelompok atau klaster, dalam 


\section{Kelayakan Usahatani Cabai Merah Dengan Sistem \\ Panen Hijau Dan Sistem Panen Merah \\ (Kasus Pada Petani Cabai di Kecamatan Sariwangi Kabupaten Tasikmalaya)}

DEDI DJULIANSAH

penelitian ini klaster dibagi menjadi dua populasi, yaitu petani cabai yang melaksanakan pemananen sistem panen merah dan pemanenan sistem panen hijau.

Menurut pendapat Amirin (1990) bahwa, apabila sampel dalam jumlah besar (lebih dari 100) sampel dapat diambil 5 persen, 10 persen sampai dengan 50 persennya, selanjutnya dihitung secara stratafikasi. Mengacu pada pernyataan di atas maka penentuan sampel dilakukan sebagai berikut : Di daerah penelitian terdapat sebanyak 145 orang petani cabai $(\mathrm{N})$, maka dengan mengambil 25 persennya dari seluruh petani cabai yaitu sebanyak 36 orang terdiri dari dua stratum berdasarkan pelaksanaan panennya pada satu musim tanam yaitu dengan perhitungan sebagai berikut :

1) Jumlah petani yang melaksanakan panen hijau sebanyak 109 orang $\left(\mathrm{N}_{1}\right)$

$$
n_{1}=\frac{N_{1}}{N} \times n \quad n_{1}=\frac{109}{145} \times 36=27
$$

(sampel petani cabai yang melakukan panen hijau $=27$ )

2) Jumlah petani yang melaksanakan panen merah sebanyak 36 orang $\left(\mathrm{N}_{2}\right)$.

$$
n_{2}=\frac{N_{2}}{N} \times n \quad n_{2}=\frac{36}{145} \times 36=9
$$

(sampel petani cabai yang melakukan panen merah $=9$ )

\section{Kerangka Analisis}

Dalam menganalisis besarnya biaya mengacu pada pendapat Tjakrawiralaksana (1983) yaitu dengan rumus sebagai berikut :

Keterangan :

$$
\mathrm{TC}=\mathrm{TFC}+\mathrm{TVC}
$$

$\mathrm{TC}=$ Total Cost (Total biaya)

TFC = Total Fixed Cost (Total biaya tetap) $\mathrm{TVC}=$ Total Variabel Cost $($ Total biaya tidak tetap)

Untuk menghitung besarnya pendapatan/keuntungan/laba, mengacu pada pendapat Mubyarto (1982), yaitu dengan rumus sebagai berikut :

$$
\pi=\mathrm{TR}-\mathrm{TC}
$$

Keterangan :

$\pi=$ pendapatan/keuntungan/laba petani (Rp)

$\mathrm{TR}=$ Total Revenue (total Penerimaan )

$\mathrm{TC}=$ Total Cost $($ Total biaya $)$

Dimana :

$$
\mathrm{TR}=\mathrm{Hy} \quad \mathrm{x} \mathrm{Y}
$$

$\mathrm{TR}=$ Total Penerimaan

$\mathrm{Hy}=$ Harga Produk

$\mathrm{Y}=$ Produk.

Untuk melihat kelayakan usahatani cabai yang menggunakan sistem pemanenan merah dan sistem pemanen hijau digunakan analisis imbangan antara penerimaan dengan biaya, yaitu dengan menggunakan rumus sebagai berikut :

$\mathrm{R}-\mathrm{C}$ ratio $=$ Penerimaan $:$ Biaya Total

Kaidah keputusan yang akan diperoleh, adalah sebagai berikut :

1. $\mathrm{R} / \mathrm{C}=1$ (Usahatani dalam keadaan tidak untung dan tidak rugi (Impas)

2. $\mathrm{R} / \mathrm{C}>1$ (Usahatani dalam keadan untung/layak untuk diusahakan

3. $\mathrm{R} / \mathrm{C}<1$ (Usahatani tersebut mengalami kerugian/tidak layak untuk diusahakan

\section{HASIL PENELITIAN DAN \\ PEMBAHASAN \\ Sarana Produksi dan Tenaga Kerja}

Untuk melaksanakan proses produksi pada pengelolaan usahatani cabai, baik yang melakukan pemanenan saat hijau maupun yang melakukan panen saat merah sudah barang tentu petani harus mengeluarkan biaya yang cukup. Penggunaan biaya tersebut seperti benih, pupuk, pestisida, maupun sarana yang lainnya serta alat-alat tentunya perlu diperhitungkan sebab biaya sarana produksi ini dapat berpengaruh terhadap pendapatan usahatani tersebut.

Selain sarana produksi yang perlu dipertimbangkan dalam proses usahatani cabai yang dipanen saat hijau maupun usahatani cabai yang dipanen saat merah yaitu masalah tenaga kerja, baik tenaga kerja dari dalam keluarga maupun dari luar keluargapun perlu diperhitungkan. Adapun besarnya upah tenaga kerja yang berlaku di Kecamatan Sariwangi 


\section{AIMBAR AgRIBISNIS

sangat variatif pada tiap-tiap desanya. Adapun upah tenaga kerja pada saat penelitian untuk satu hari kerja tenaga pria adalah antara Rp.15.000,00. sampai dengan Rp.20.000,00 dan Rp. 8.000,00 sampai dengan Rp.10.000,00 untuk tenaga kerja wanita. Sedangkan untuk tenaga kerja dalam keluarga, upah tenaga kerjanya diperhitungkan sama seperti upah tenaga kerja dari luar keluarga.

\section{Analisis Biaya Usahatani Cabai yang Dipanen saat Hijau dan yang Dipanen saat Merah \\ Biaya Tetap}

Komponen biaya tetap yang dihitung dalam penelitian ini meliputi :

a) Sewa lahan, yaitu dengan kisaran antara Rp.5.600.000,00 sampai Rp.7.000.000,00 per hektar per tahun dan hal ini tergantung kelas lahan, kesuburan tanah serta keadaan lokasinya.

b) Penyusutan alat-alat yang digunakan dalam pelaksanaan usahatani cabai baik yang dipanen saat hijau maupun yang dipanen saat merah, karena kebanyakan petani memilikinya seperti cangkul, parang, sabit, gunting stek, garpu, golok, timbangan, hand sprayer, ember, drum dan embrat atau gembor.

c) Bunga modal tetap, adalah bunga bank yang berlaku pada saat penelitian yaitu sebesar 12 persen per tahun untuk bunga pinjaman. Sehingga bunga modal yang diperhitungkan per satu periode produksi sebesar 6 persen, walaupun modal yang digunakan adalah modal sendiri.

Untuk lebih jelasnya mengenai rata-rata biaya tetap pada usahatani cabai yang melakukan pemanenan saat hijau dan usahatani cabai yang melakukan pemanenan saat merah di Kecamatan Sariwangi Kabupaten Tasikmalaya dapat dilihat pada Tabel 1.

Tabel 1. Rata-rata Biaya Tetap per Hektar per Satu Periode Produksi pada Usahatani Cabai yang Dipanen Sistem Hijau dan Usahatani cabai yang Dipanen Sistem Merah

\begin{tabular}{|c|c|c|c|c|c|}
\hline \multirow{2}{*}{ No. } & \multirow{2}{*}{ Macam Pengeluaran } & \multicolumn{2}{|c|}{ Petani Cabai Panen Hijau } & \multicolumn{2}{|c|}{ Petani Cabai Panen Merah } \\
\hline & & Jumlah (Rp/ha) & Persen (\%) & Jumlah (Rp/ha) & Persen (\%) \\
\hline 1. & Sewa Lahan & $6.820 .106,-$ & 83,36 & $6.638 .177,-$ & 84,10 \\
\hline 2. & Penyusutan alat & $898.337,-$ & 10,98 & $808.177,-$ & 10,23 \\
\hline 3. & Bunga modal & 463.106,- & 5,66 & $446.782,-$ & 5,67 \\
\hline & $\mathrm{Ju} \mathrm{m} \mathrm{lah}$ & $8.181 .549,-$ & 100.00 & 7.893 .136 - & 100.00 \\
\hline
\end{tabular}

Tabel 1 menunjukkan bahwa biaya tetap untuk usahatani cabai yang dipanen hijau yaitu Rp. 8.181.549,- $\quad$ sedangkan pada usahatani cabai yang dipanen saat merah hanya sebesar Rp.7.893.136,-. Hal ini terjadi karena pada usahatani cabai yang dipanen merah, komponen biaya sewa lahan lebih kecil dari cabai panen hijau, hal ini disebabkan karena kebanyakan petani menggunakan tanah darat, sedangkan yang dipanen hijau petani banyak menggunakan lahan sawah jadi biaya untuk sewa lahan lebih besar. Disamping itu peralatan usahatani yang dimiliki petani cabai yang melaksanakan panen hijau lebih banyak dari petani yang melaksanakani panen merah, sehingga nilai penyusutan alatnya lebih besar.

\section{Biaya Variabel}

Komponen biaya variabel yang dihitung pada usahatani cabai panen merah dan cabai panen hijau meliputi benih, pupuk (urea, SP-36, $\mathrm{KCl}$ ), pestisida dan tenaga kerja.

Untuk lebih jelasnya mengenai ratarata besarnya biaya variabel per hektar per satu periode produksi dapat dilihat pada Tabel 2 . 
Kelayakan Usahatani Cabai Merah Dengan Sistem

Panen Hijau Dan Sistem Panen Merah

(Kasus Pada Petani Cabai di Kecamatan Sariwangi Kabupaten Tasikmalaya)

DEDI DJULIANSAH

Tabel 2. Rata-rata Biaya Variabel per Hektar per Satu Periode Produksi pada Usahatani Cabai Sistem Panen Merah dan Usahatani Cabai Sistem Panen Hijau

\begin{tabular}{|l|l|l|l|l|l|}
\hline \multirow{2}{*}{ No. Macam Pengeluaran } & \multicolumn{2}{c|}{ Cabai Panen Merah } & \multicolumn{2}{c|}{ Cabai Panen Hijau } \\
\cline { 3 - 6 } & \multicolumn{1}{|c|}{$\begin{array}{c}\text { Jumlah (Rp/ha) } \\
(\mathbf{\%})\end{array}$} & \multicolumn{1}{|c|}{ Jumlah (Rp/ha) } & $\begin{array}{c}\text { Persen } \\
(\%)\end{array}$ \\
\hline 1. & Benih & $1.089 .744,-$ & 1,47 & $1.087 .303,-$ & 1,80 \\
2. & Polibag & $185.185,-$ & 0,25 & $185.186,-$ & 0,30 \\
3. & Plastik Tranparan & $598.290,-$ & 0,79 & $577.777,-$ & 0,95 \\
4. & Mulsa Plastik & $7.110 .659,-$ & 9,62 & $7.043 .386,-$ & 11,66 \\
5. & Tali Rapia & $484.331,-$ & 0,65 & $328.043,-$ & 0,54 \\
6. & Ajir bambu & $3.461 .538,-$ & 4,68 & $3.486 .243,-$ & 5,77 \\
7. & Pupuk Kandang & $3.461 .538,-$ & 4,68 & $3.355 .026,-$ & 5,55 \\
8. & Pupuk Anorganik & $7.816 .523,-$ & 10,58 & $7.795 .714,-$ & 12,90 \\
9. & Pupuk Daun & $1.388 .890,-$ & 1,88 & $1.148 .571,-$ & 1,90 \\
10. & Kapur Pertanian & $534.187,-$ & 0,72 & $530.529,-$ & 0,87 \\
11. & Pestisida & $16.139 .600,-$ & 21,85 & $6.530 .160,-$ & 10,82 \\
12. & Tenaga Kerja & $27.393 .162,-$ & 37,17 & $24.914 .286,-$ & 41,06 \\
13. & Bunga Modal & $4.181 .795,-$ & 5,66 & $3.418 .934,-$ & 5,66 \\
\hline \multicolumn{1}{|c|}{ Jumlah } & $\mathbf{7 3 . 8 5 4 . 4 4 1 , -}$ & $\mathbf{1 0 0 , 0 0}$ & $\mathbf{6 0 . 4 0 1 . 1 5 7 , -}$ & $\mathbf{1 0 0 , 0 0}$ \\
\hline
\end{tabular}

Tabel 2 menunjukkan, bahwa jumlah biaya variabel pada usahatani cabai panen merah per hektar per satu periode produksi adalah Rp. 73.854.441,-, dan pada usahatani cabai panen hijau lebih kecil bila dibandingkan dengan usahatani cabai panen merah yaitu sebesar Rp.60.401.157,-. Penambahan biaya variabel ini karena biaya pestisida yang dikeluarkan untuk cabai panen merah lebih besar dari cabai panen hijau, hal ini disebabkan, agar produk yang dihasilkan tidak rusak atau terganggu oleh serangan penyakit.

\section{Biaya Total}

Biaya total adalah merupakan penjumlahan antara biaya tetap dengan biaya variabel. Rata-rata biaya total per hektar per satu periode produksi pada petani cabai panen merah sebesar Rp. 81.747.577,- dan pada petani cabai panen hijau yaitu sebesar

Rp. 68.582.706,-. Untuk lebih jelasnya dapat dilihat pada Tabel 3

Tabel 3. Rata-rata Biaya Total per Hekta per Satu Periode Produksi pada Usahatani Cabai Sistem Panen Merah dan Usahatani Cabai Sistem Panen Hijau

\begin{tabular}{|l|l|l|l|l|}
\hline \multirow{2}{*}{\multicolumn{1}{c|}{ Macam Pengeluaran }} & \multicolumn{4}{|c|}{ Jenis Usahatani } \\
\cline { 2 - 5 } & \multicolumn{2}{|c|}{ Cabai Panen Merah } & \multicolumn{2}{c|}{ Cabai Panen Hijau } \\
\cline { 2 - 5 } & $\begin{array}{c}\text { Jumlah } \\
(\mathbf{R p})\end{array}$ & $\begin{array}{c}\text { Persentase } \\
(\boldsymbol{\%})\end{array}$ & $\begin{array}{c}\text { Jumlah } \\
(\mathbf{R p})\end{array}$ & $\begin{array}{c}\text { Persentase } \\
(\boldsymbol{\%})\end{array}$ \\
\hline Biaya Tetap & $7.893 .136,-$ & 9,65 & $8.181 .549,-$ & 11.93 \\
Biaya Variabel & $73.854 .441,-$ & 90,35 & $60.401 .157,-$ & 88,07 \\
\hline J u m I a h & $\mathbf{8 1 . 7 4 7 . 5 7 7 , -}$ & $\mathbf{1 0 0 , 0 0}$ & $\mathbf{6 8 . 5 8 2 . 7 0 6 . -}$ & $\mathbf{1 0 0 , 0 0}$ \\
\hline
\end{tabular}

Tabel 3 menunjukkan bahwa jumlah biaya tetap yang dikeluarkan pada usahatani cabai panen merah lebih besar, bila dibandingkan dengan usahatani cabai panen hijau. Hal ini karena pada usahatani cabai panen merah, komponen biaya pestisida dan biaya tenaga kerja lebih besar dari cabai panen hijau.
Analisis Pendapatan dan R-C ratio Usahatani Cabai Sistem Panen Hijau dan Sistem Panen Merah

Analisis pendapatan dan R/C digunakan untuk mengukur berhasil tidaknya suatu usahatani yang dijalankannya dengan tujuan untuk memperoleh pendapatan yang sebesar-besarnya, maka besarnya pendapatan akan mencerminkan hasil usahatani yang baik, sedangkang jika nilai $\mathrm{R} / \mathrm{C}>1$, ini mencerminkan bahwa sistem pemanen yang 


\section{A MIMBAR AGRIBISNIS \\ ISSN 2460-432}

Volume 1 • Nomor $3 \bullet$ Juli 2016

dilaksanakan saat ini oleh petani layak untuk diteruskan.

Besarnya rata-rata penerima per hektar dari usahatani cabai dengan sistem pemanen hijau adalah sebesar Rp. 91.515.715,dan untuk panen sistem merah adalah sebesar Rp. 117.896.810,-

Besarnya rata-rata keuntungan per hektar per satu periode produksi pada usahatani cabai panen merah dan usahatani cabai panen hijau dapat dilihat pada Tabel 4

Tabel 4. Rata-rata Keuntungan per Hektar per Satu Periode Produksi pada Usahatani cabai Sistem Panen Merah dan Usahatani Cabai Sistem Panen Hijau

\begin{tabular}{|c|c|c|c|}
\hline No. & $\begin{array}{l}\text { Macam } \\
\text { Usahatani }\end{array}$ & $\begin{array}{c}\text { Keuntungan } \\
(\mathbf{R p})\end{array}$ & R-C \\
\hline \multirow[t]{2}{*}{$\begin{array}{l}1 . \\
2 .\end{array}$} & $\begin{array}{l}\text { Cabai panen } \\
\text { merah }\end{array}$ & $233,-$ & 1,44 \\
\hline & $\begin{array}{l}\text { Cabai panen } \\
\text { hijau }\end{array}$ & 22.933.009,- & 1,33 \\
\hline
\end{tabular}

Tabel 4 menunjukkan bahwa besarnya rata-rata pendapatan maupun $\mathrm{R}-\mathrm{C}$ ratio pada usahatani cabai panen merah lebih besar daripada usahatani cabai panen hijau. Hal ini karena penerimaan pada usahatani cabai panen merah lebih besar dan sebaliknya, penerimaan pada usahatani cabai panen hijau lebih kecil.

\section{SIMPULAN DAN SARAN Simpulan}

Berdasarkan hasil penelitian dan pembahasan dapat disimpulkan bahwa usahatani cabai yang dipanen dengan sistem merah jauh lebih besar, baik dilihat dari besarnya biaya yang harus dikeluarkan, maupun penerimaan dan pendapatan yang diperoleh serta dari nilai R-C yang dihasilkan.

\section{Saran}

Jika dilihat dari nilai R-C kedua sistem ini layak untuk diusahakan, namun demikian sistem panen merah dapat memberikan keuntungan yang lebih baik bagi petani. Berdasarkan hal tersebut nampaknya bantuan pendanaan perlu dilanjutkan agar petani cabai mau dan mampu untuk melakukan panen pada saat cabai telah merah, tentu saja pembinaan dan evaluasi terhadap sikap dan prilaku petani perlu terus dilakukan serta jaminan kepastian harga baik harga faktor produksi maupun harga jual akan sangat menentukan keberhasilan suatu kegiatan usahatani

\section{DAFTAR PUSTAKA}

Adiwilaga A. 1982. Ilmu Usahatani. Alumni, Bandung.

Amirin T.M. 1990. Menyusun Rencana Penelitian. CV. Rajawali, Jakarta.

Mubyarto. 1982. Pengantar Ekonomi Pertanian. LP3ES, Jakarta.

Nazir. 1998. Metode Penelitian. Ghalia Indonesia, Jakarta.

Soeharjo. 1980. Ekonomi Pertanian. Departemen Ilmu-ilmu Sosial Ekonomi Pertanian, Fakultas Pertanian. Institut Pertanian Bogor, Bogor.

Soeharto Prawirokusumo. 1990. Ilmu Usahatani. BPFE, Yogyakarta.

Soekartawi. 1985. Pembangunan Pertanian. PT. Raja Grafindo Persada, Jakarta.

Tjakrawiralaksana. 1983. Usaha Tani. Departemen Ilmu-ilmu Sosial Ekonomi Pertanian, Fakultas Pertanian. IPB., Bogor. 